\title{
Trust and Trustworthiness of Friendship Relation in Yogyakarta and Makassar
}

\author{
Faturochman ${ }^{1}$, Wenty Marina Minza ${ }^{2}$, Muh. Reza Firmansyah ${ }^{3}$ \\ Center for Indigenous and Cultural Psychology \\ Faculty of Psychology, Universitas Gadjah Mada
}

Submitted 08 April 2019 Accepted 30 May 2020 Published 24 August 2020

\begin{abstract}
Previous research conducted by the same authors found that personal attributes (benevolence, integrity, competence) and the relational attributes (closeness, support, and reciprocity) influence trust and trustworthiness. This paper aimed to test the proposed trust model on a new dataset while also testing for gender and regional differences. This research involved a collaboration between Universitas Gadjah Mada as a representative from Yogyakarta and Universitas Negeri Makassar as a representative from Makassar. There were 420 students that participated in this study; 157 (37.4\%) men and 263 (62.6\%) women. Regression analyses indicated that $42 \%$ of trust was formed by personal and relational attributes. Contrary to expectations, there were no differences in trust $(p>0.05)$ between females and males. However, there was a significant difference in trustworthiness $(p<0.01)$ between women and men. Furthermore, this paper also found that there were no differences in trust between the regions; Yogyakarta and Makassar $(p>0.05)$. This study provides an understanding on the importance of trust and trustworthiness in efforts to maintain pluralism, as a form of citizenship identity.
\end{abstract}

Keywords: friendship; personal attributes; relational attributes; trust; trustworthiness

Humans are social creatures that have a need to socialize with one another. This tendency cannot not be separated from the evolution of human beings who rely on social relationships (Bersceid \& Regan, 2005) to enhance survival capacities in both the physical and psychological aspects (Fiske, 2004). In order to create solid relationships, trust is needed (Simpson, 2007), since it constitutes one of the fundamental elements of social relationships (Igarashi, 2008).

Trust refers to a psychological state of which an individual takes a risk and discloses some aspects of themselves to another person on the condition that

\footnotetext{
${ }^{1}$ Address for correspondence: wminza@ugm.ac.id
}

positive relations are maintained between them (Hardin, 1996). Other definitions of trust highlight the aspect of willing to be vulnerable (easily attacked or hurt) based on people's positive expectations toward their relationships with other people (Mayer, Davis, \& Schoorman, 1995; Rousseau, Sitkin, Burt, \& Camerer, 1998). Despite this, trust cannot grow without considering the other person's trustworthiness (Kim et al., 2009).

Trustworthiness is an antecedent of trust or in other words, trust grows with the presence of trustworthiness (Sekhon, Ennew, Kharouf, \& Devlin, 2014). Trustworthiness can take the form of values or individual characteristics which are expressed in the behaviors that 
precede trust (Bews \& Roussouw, 2002). Although trust and trustworthiness are distinct, they are viewed as essentially the same. Within the realms of interpersonal relations, both trust and trustworthiness are one construct (Robbins, 2016). In line with this, Faturochman and Minza (2014) found that both trust and trustworthiness are composed of identical attributes, namely personal attributes and relational attributes. While personal attributes consists of benevolence, integrity, and competence, the relational attributes consists of closeness, support, and reciprocity.

Trust and trustworthiness therefore become an essential component of social relations since it involves a person's knowledge toward other individuals (Kim et al., 2009). This in line with Flanagan and Stoutu (2010) who suggested that an individual's experience in building relations is an important element of building trust and trustworthiness. In simple terms, trust emerges because of a person's trustworthiness and the relationship will continue to thrive when positive relations are maintained (Hardin, 1996). Apart from family relations, friendship is also a form of intense social relations (Taylor, Peplau, \& Sears, 2009) with trust as its main feature (Bergsieker, 2012). Without trust, friendships may frequently break up which is consistent with research reporting that $71 \%$ of friends have betrayed their friends (Anastassia \& Faturochman, 2014).

Numerous aspects affect trust. Rotenberg et al., (2005) suggested reliability, refraining to hurt another person (emotional aspect), and honesty (sharing personal stories with another person) are all important aspects that affect trust. On the other hand, some researchers use the term interpersonal trust which is composed of two main dimensions namely the cognitive and affective dimension (Ferris, Lian, Pang, \& Keeping, 2010; McAllister, 1995). The cognitive dimension is composed of reliability, integrity, honesty, and justice while the affective component is composed of all the positive outcomes experienced while interacting with another person (Ferris et al., 2010; McAllister, 1995). From a gender perspective, males show more trust to others compared to females. However, women are known to be more trustworthy than men, and this is because women are better at reciprocating the trust which has been granted to them (Buchan, Croson \& Solnick, 2008). Research by Mayer et al. (1995) showed that ability, benevolence, and integrity are all important aspects that affect trust. While Mayer et al. (1995) used the term personal qualities, Faturochman and Minza (2014) referred to these qualities as personal attributes.

Most of the psychological literatures on trust focuses on dyadic relationships, or interactions between the trustee (person who is trusted) and the trustor (person who gives the trust). Furthermore, trust is only given to people who are trustworthy, and therefore the focus is on the trustor. This is in spite of the fact that trust is characterized by a mutual interaction between the trustee and the trustor (Faturochman \& Minza, 2014).

Past research conducted by Faturochman and Minza (2014) suggested that trust and trustworthiness does not simply rely on personal attributes but also a relational attribute. Personal attributes are associated with personal qualities which include benevolence, integrity, and competence. While relational attributes consists of support, closeness, and reciprocity. Both these attributes affect and become predictors of trust and trust- 
worthiness (Faturochman \& Minza, 2014). The attributes in discussion are benevolence, integrity, competence, closeness, support and reciprocity.

Benevolence refers to a basic preference for an individual to act kindly toward other people. Benevolence is related to trust because it signifies a commitment to act kindly toward the trustor (Mayer et al., 1995). Integrity refers to authenticity or honesty in presenting one's true self (Snyder \& Lopez, 2007). In other references, integrity is defined as a principle component that can be found within the trustor and accepted by the trustee, and vice versa (Mayer et al., 1995).

Competence can be defined as a personal ability in relation to a person's acquisition of knowledge. In the context of social relations, competence ideally functions as a person's knowledge base to interpret and respond to different situations as well as responding to other people (Snyder \& Lopez, 2007). Furthermore, Robert (2001) suggests that knowledge and skills are part of competence which can be acquired through learning.

Closeness is perhaps one of the best predictors of determining relationships between people (Sears, Freedman \& Peplau, 1985). Closeness does not simply mean close in proximity but it relates with emotional closeness which is characterized by intense relations between two people, which in turn determines the quality of trust between the trustee and trustor (Faturochman \& Minza, 2014)

Hamaguchi (1977) placed support as one of the aspects of building trust. Support is given as a form of appreciation or assistance in both material and/or nonmaterial forms. This involves contribution of the trustor as a form of acceptance and openness towards the trustee, and vice versa (Snyder \& Lopez, 2007).
Some research has shown that people tend to maintain behaviors in relationships that are mutually beneficial (Sears et al., 1985), because such acts are perceived to give a sense of justice (Walster, Walster \& Berscheid, 1978). In a relationship, there may be some needs that are facilitated by reciprocity which will lead to the growth of trust between the partners (Faturochman \& Minza, 2014).

Figure 1 shows the framework suggested by Faturochman and Minza (2014) in their article "Exploring personal and relational trustworthiness".

Based on figure 1, Faturochman \& Minza (2014) found that relational attributes (closeness, support, and reciprocity), are in stark contrast with Mayer and colleagues' research (1995) who found that trust was based on personal qualities. Therefore, the framework proposed by Faturochman \& Minza (2014) complement the need for relational quality (relational attributes) which is composed of closeness, support and reciprocity. Furthermore research has shown that trust and trustworthiness are relational attributes, while personal attributes serve complementary roles (Rahmanawati, Ferdian, Widyastuti, Faturochman, \& Minza, 2020). Meanwhile, aspects of personal attributes play the most significant role in affecting trust in friendship relations, particularly the benevolence aspect (Firmansyah, Amelia, Jamil, Faturochman, \& Minza 2019).

Based on the elaborations concerning trust and trustworthiness, the goal of the current study is to test Faturochman and Minza's (2014) model of trust and trustworthiness in the context of friendship relations among participants living in Yogyakarta and Makassar. This paper will also investigate gender and regional differences concerning trust and 
trustworthiness using the model proposed by Faturochman and Minza (2014).

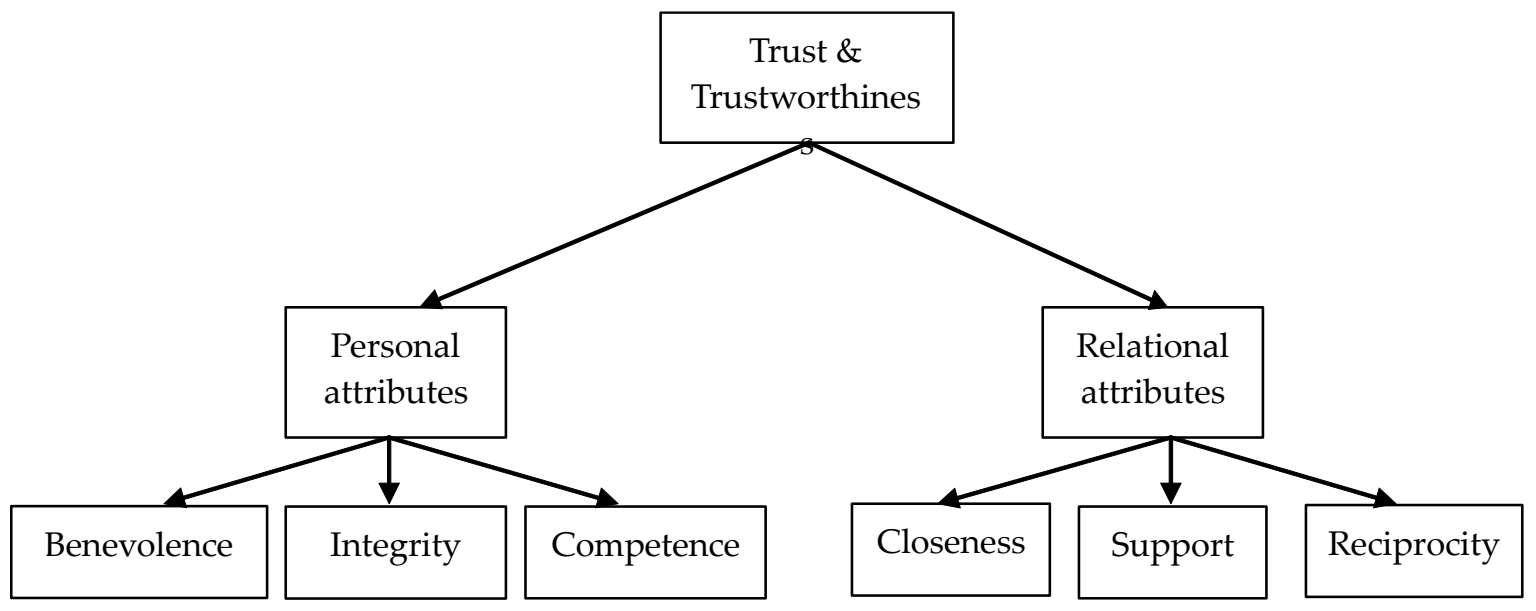

Figure 1. Attributes that affect trust and trustworthiness

(Faturochman \& Minza, 2014)

Yogyakarta and Makassar are part of the Indonesian Republic and both societies tend to have a collective orientation whereby their behaviors are largely guided by social norms (Taylor et al., 2009). However, both communities tend to focus on different aspects in building relationships and therefore we can assume that different attributes are at play when related to trust and trustworthiness. In Yogyakarta, which is dominated by the Javanese ethnicity, one of the foundations for building relationships is harmony. For Javanese, harmony relates with benevolence, understanding, and respect to other people as a fundamental value in building relationships (Dewi, Weinehall \& Öhman, 2010). Meanwhile, member of the Bugis-Makassar community places more emphasis on honesty (lempu'), saying the right things (ada tonggeng), and consistency in holding principles referred to as getteng (Badewi, 2019). Therefore, we can assume that trust and trustworthiness in Yogyakarta would be determined by personal and relational attributes of benevolence, support and reciprocity. While among the Makassar community, trust and trustworthiness would be affected by the personal attributes of integrity. This rationale leads to three hypotheses. First, trust is affected by personal and relational attributes. Second, there is a difference of trust between genders, and third, there is a difference of trust depending on regional differences.

\section{Method}

This research was a collaborative project between Universitas Gadjah Mada and Universitas Negeri Makassar. Data were collected from participants living in Yogyakarta and Makassar with the aim to explore how trust and trustworthiness in friendship relations are affected by the six aspects of trust and trustworthiness as proposed by Faturochman and Minza (2014). This research employed a quantitative approach and a survey was used for collecting data.

\section{Participants}

Participants were students from Universitas Gadjah Mada. These students represented the Yogyakarta sample, while 
students from Universitas Negeri Makassar (UNM) constituted the Makassar sample. The participants from UGM were recruited from the Faculty of Psychology and Faculty of Engineering with a total of 220 students, consisting of 97 males $(44.1 \%)$ and 123 females (55.9\%). Participants from UNM were recruited from the Faculty of Psychology with a total of 200 students, consisting of 64 males (32\%) and 136 females (68\%). Therefore, the total number of respondents were 420 participants, with 161 males $(38.3 \%)$ and 259 females $(61.7 \%)$, all of which is presented in the Table 2.

\section{Procedure and research instruments}

The participants were asked to complete a Likert scale with items developed from Faturochman and Minza (2014). The instrument measured personal attributes (benevolence, competence, and integrity), relational attributes (support, closeness, and reciprocity) and trust. The participants in this study took the position of the trustor and they were asked to imagine a friend and indicate the gender of the friend. Afterwards, the participant answered a series of questions related to the personal characteristics of the friend (benevolence, competence, integrity), their relational attributes, (support, closeness, and reciprocity), and trust. A list of the measures and a description are given below.

\section{Personal Trustworthiness scale}

Benevolence subscale. This subscale consisted of 5 items. The average score was $5.39(S D=1)$, which showed that most respondents answered 5 on the scale. The following is a sample item "hel she likes to entertain people who are experiencing distress."

Competence subscale. This subscale consisted of 6 items with an average score of $5.08(S D=1.02)$ indicating that most respondents answered 5. A sample of the scale is "he/she has a broad perspective"

Integrity Subscale. This subscale consisted of 5 items and had an average score of 5.56 $(S D=0.92)$ indicating that most participants answered 5 or 6 . A sample item from the scale is "helshe can give the right information"

\section{Relational Trustworthiness Scale}

Support Subscale. This subscale consisted of 6 items and had an average score of 5.14 $(S D=1.07)$, indicating that participants mostly answered 5. Based on factor analyses, $61.13 \%$ of the cumulative variance was explained by the factor solution. A sample item is "he/she is able to motivate me."

Table 2.

Research Participants

\begin{tabular}{lcccc}
\hline \multirow{2}{*}{ Respondents' gender } & \multirow{2}{*}{ Total } & \multicolumn{2}{c}{ Region } & \multirow{2}{*}{ Total } \\
\cline { 3 - 4 } & & Yogyakarta & Makassar & \\
\hline \multirow{2}{*}{ Male } & $\mathrm{N}$ & 97 & 64 & 161 \\
& $\%$ & 23.1 & 15.2 & 38.3 \\
\multirow{2}{*}{ Female } & $\mathrm{N}$ & 123 & 136 & 259 \\
& $\%$ & 29.3 & 32.4 & 61.7 \\
\hline \multirow{2}{*}{ Total } & $\mathrm{N}$ & 220 & 200 & 420 \\
& $\%$ & 52.4 & 47.6 & 100.0 \\
\hline
\end{tabular}


Closeness Subscale. This sub-scale consisted of 5 items and had an average score of $5.54(S D=1.33)$, indicating that most participants answered 5 or 6 in the scale; the following is a sample item "he/she knows me very well."

Reciprocity Subscale. This subscale consisted of 5 items and had an average score of $5.61(S D=1.12)$ meaning that most respondents answered 5 or 6 . A sample item is "he/she likes to give things to each other."

Trust Scale. This scale consisted of 6 items which measured trust. The average score was $4.92(S D=0.97)$, meaning that most respondents answered 4 or 5 on the scale. A sample item is "my friend is always honest to me."

In this study, a 7 point Likert scale was used $(1=$ not agree at all $7=$ absolutely agree), and the participants were asked to rate whether the statements accurately represented their trust to their friend. This instrument had been tested and had a reliability higher than 0.7 with correlations ranging from $0.4-0.8$.

\section{Data analyses}

This research used a quantitative approach using t-test and regression to test the hypothesis. T-test was used to test differences of trust and trustworthiness based on demographic differences. The demographic differences that were tested included gender, friend's gender, and region (Yogyakarta and Makassar). The analyses was followed by simple regression to test the effects and proportion of variances accounted for the model. In the analyses, trust was placed as the dependent variable; while personal and relational attributes served as the independent variables.

Table 3.

Research Instruments

\begin{tabular}{|c|c|c|c|c|}
\hline \multirow[b]{2}{*}{ Variable } & & \multicolumn{2}{|c|}{ Reliability } & \multirow{2}{*}{$\begin{array}{c}\text { Factor analyses } \\
\begin{array}{c}\text { Cumulative } \\
\text { variance }\end{array}\end{array}$} \\
\hline & & $\begin{array}{l}\text { Item-total } \\
\text { Correlation }\end{array}$ & $\begin{array}{c}\text { Cronbach } \\
\text { Alpha }\end{array}$ & \\
\hline \multirow[t]{3}{*}{ Personal attribute } & Benevolence & $.53-.70$ & .85 & $58.76 \%$ \\
\hline & Competence & $.48-.74$ & .84 & $61.21 \%$ \\
\hline & Integrity & $.47-.67$ & .77 & $53.57 \%$ \\
\hline \multirow[t]{3}{*}{ Relational attribute } & Support & $.49-.77$ & .87 & $61.13 \%$ \\
\hline & Closeness & $.77-.87$ & .93 & $78.86 \%$ \\
\hline & Reciprocity & $.74-.84$ & .92 & $76.08 \%$ \\
\hline Trust & & $.41-.58$ & .74 & $69.47 \%$ \\
\hline
\end{tabular}




\section{TRUST AND TRUSTWORTHINESS OF FRIENDSHIP RELATION}

\section{Results Regression analyses}

Data

Table 4 presents descriptive analyses of the main variables in the study.
Based on the 420 respondents from Yogyakarta and Makassar who participated in this study, the following models were derived (Table 5, 6, and 7).

Table 4.

Descriptive Statistics of Main Variables

\begin{tabular}{llcccc}
\hline \multicolumn{1}{c}{ Variable } & Aspects & Minimum & Maximum & Average & $\begin{array}{c}\text { Standard } \\
\text { Deviation }\end{array}$ \\
\hline Personal & Benevolence & 1.33 & 7.00 & 5.39 & 1.00 \\
attributes & Competence & 1.00 & 7.00 & 5.08 & 1.02 \\
& Integrity & 2.20 & 7.00 & 5.56 & 0.92 \\
Relational & Support & 1.00 & 7.00 & 5.14 & 1.07 \\
attributes & Closeness & 1.00 & 7.00 & 5.54 & 1.33 \\
& Reciprocity & 1.00 & 7.00 & 5.61 & 1.12 \\
Trust & & 1.50 & 7.00 & 4.92 & 0.97 \\
\hline
\end{tabular}

Table 5.

Model 1: Trust in Friendship

\begin{tabular}{lcccc}
\hline \multicolumn{1}{c}{ Aspect } & Standardized Beta & $\mathbf{t}$ & $\mathbf{F}$ & $\mathbf{R}^{2}$ \\
\hline Benevolence & .074 & $1.341^{\text {ts }}$ & $51.73^{*}$ & .42 \\
Competence & -.018 & $-.381^{\text {ts }}$ & & \\
Integrity & .245 & $4.979^{*}$ & & \\
Support & .289 & $4.729^{*}$ & & \\
Closeness & -.006 & $-.105^{\text {ts }}$ & & \\
Reciprocity & .190 & $3.045^{*}$ & & \\
\hline
\end{tabular}

Note: ${ }^{*}=\mathrm{p}<.01 ;{ }^{* *}=\mathrm{p}<.05 ;$ ts $=$ Not significant

Table 6.

Model 2 : Trust in Friendship among Students in Yogyakarta

\begin{tabular}{lcccc}
\hline \multicolumn{1}{c}{ Aspect } & Standardized Beta & $\mathbf{t}$ & $\mathbf{F}$ & $\mathbf{R}^{2}$ \\
\hline Benevolence & .153 & $2.279^{*}$ & $28.51^{*}$ & .43 \\
Competence & -.162 & $-2.476^{* *}$ & & \\
Integrity & .149 & $2.157^{* *}$ & & \\
Support & .375 & $4.247^{*}$ & & \\
Closeness & -.006 & $-.063^{\text {ts }}$ & & \\
Reciprocity & .213 & $2.394^{* *}$ & & \\
\hline
\end{tabular}

Note: ${ }^{*}=\mathrm{p}<.01 ;{ }^{* *}=\mathrm{p}<.05 ; \mathrm{ts}=$ Not significant 
Model 1 showed the trust model for friendships collapsing regional differences. The $R^{2}$ was 0.42 or $42 \%$ which suggests that $42 \%$ of trust was formed by personal and relational attributes. Some personal attributes did not significantly predict trust namely benevolence and competence; and while closeness was categorized within the relational aspect of trust this was not significant. In contrast, integrity (relational attribute), support (relational attribute), and reciprocity (relational attribute) were significant $(p<0.01)$ indicating that these aspects were important predictors of trust. The correlation coefficient $(\beta)$ for integrity, support and reciprocity were positive indicating that all three variables were positively associated with trust. This meant that higher integrity, support and reciprocity would all lead to higher trust. Therefore, we can say that integrity, support and reciprocity gave a significant effect on trust.

Model 2 showed the trust model for respondents living only in Yogyakarta. The $R^{2}$ was 0.43 or $43 \%$. This indicated that $43 \%$ of trust in Yogyakarta was formed by personal and relational attributes. Furthermore the results showed that among those attributes, closeness (relational attribute) was not significant. This showed that closeness was not associated with trust; while the other 5 aspects had a significant effect on trust (benevolence, competence, integrity, support, and reciprocity). The correlation coefficient $(\beta)$ from benevolence, integrity, support, and reciprocity was positive which indicated that those four attributes positively associated with trust; while the correlation coefficient $(\beta)$ for competence was negative indicating that competence was negatively associated with trust. This meant that higher benevolence, integrity, support, and reciprocity, would lead to higher trust; and the higher the competence, the lower the trust.

Model 3 showed the trust model for respondents from Makassar. The $R^{2}$ was 0.44 and only integrity was shown to be a significant predictor of trust $(p<0.01)$; while the other factors were not significant. Therefore the analyses indicated that $44 \%$ of trust in Makassar was formed by integrity. The correlation coefficient $(\beta)$ for integrity was positive and so this attribute was positively associated with trust. This meant the higher the integrity the higher the trust.

Table 7.

Model 3: Trust in Friendship Among Makassar Respondents

\begin{tabular}{lcccc}
\hline \multicolumn{1}{c}{ Aspect } & Standardized Beta & $\mathbf{t}$ & $\mathbf{F}$ & $\mathbf{R}^{2}$ \\
\hline Benevolence & -.064 & $-.484^{\text {ts }}$ & $14.03^{*}$ & .44 \\
Competence & .137 & $1.367^{\text {ts }}$ & & \\
Integrity & .369 & $2.960^{*}$ & & \\
Support & .204 & $1.283^{\text {ts }}$ & & \\
Closeness & -.011 & $-.087^{\text {ts }}$ & & \\
Reciprocity & .155 & $1.160^{\text {ts }}$ & & \\
\hline
\end{tabular}

Notes: ${ }^{*}=\mathrm{p}<.01 ;{ }^{* *}=\mathrm{p}<.05 ;$ ts $=$ not significant 


\section{Test of differences}

Tests were then conducted to observe whether trust and trustworthiness were different based on gender and the regions. The results are presented in Table 8 below.

The results showed that there were no differences in trust $(p>0.05)$ between male and female participants (See Table 8). The personal and relational attributes benevolence, competence, integrity, and closeness also did not show to have any significant difference between male and female participants $(p>0.05)$. However there was a significant gender difference for the aspects of reciprocity $(p<0.05)$ and support $(p<0.01)$. Probing this test, we found that for the aspects reciprocity and support, females had higher average scores compared to male respondents.

The analyses showed that there was a significant difference for trustworthiness $(p<0.01)$ depending on the gender of the participant's friend (See Table 9). Concerning the personal attributes, there was a difference for the aspect integrity ( $p$ $<0.01$ ); while for the relational attributes, there was a difference $(p<0.01)$ on all aspects (support, closeness, and reciprocity). Further analyses showed that female friends were more trustworthy compared to male friends.

The analyses showed no significant differences of trust $(p>0.05)$ between respondents living in Yogyakarta and Makassar (See Table 10). For the personal attributes, benevolence and integrity, there was no significant difference $(p>0.05)$ between the two regions; meanwhile there was a significant difference for competence $(p<0.05)$, where respondents from Makassar had higher scores compared to respondents in Yogyakarta. This meant that competence has larger effect on trust in Makassar compared to Yogyakarta. For the relational attributes, there was a differences for closeness and reciprocity $(p<0.01)$ between the two regions; while there was no significant difference for the aspect of support $(p>0.05)$. For the aspects of closeness and reciprocity, scores were higher among respondents in Yogyakarta compared to Makassar.

Table 8.

Difference between of Trust and Trustworthiness Aspects Based on Participants' Gender

\begin{tabular}{|c|c|c|c|c|c|}
\hline \multirow[b]{2}{*}{ Variable } & \multirow[b]{2}{*}{ Aspect } & \multicolumn{2}{|c|}{ Respondents } & \multirow[b]{2}{*}{$\mathbf{F}$} & \multirow[b]{2}{*}{$\mathbf{p}$} \\
\hline & & $\begin{array}{c}\text { Male } \\
(n=152)\end{array}$ & $\begin{array}{l}\text { Female } \\
(\mathrm{n}=268)\end{array}$ & & \\
\hline \multirow[t]{3}{*}{ Personal attributes } & Benevolence & $\begin{array}{c}5.34 \\
(0.084)\end{array}$ & $\begin{array}{c}4.41 \\
(0.060)\end{array}$ & 0.47 & $>0.05$ \\
\hline & Competence & $\begin{array}{c}5.09 \\
(0.088)\end{array}$ & $\begin{array}{c}5.08 \\
(0.060)\end{array}$ & 0.03 & $>0.05$ \\
\hline & Integrity & $\begin{array}{c}5.53 \\
(0.075)\end{array}$ & $\begin{array}{c}5.57 \\
(0.056)\end{array}$ & 0.21 & $>0.05$ \\
\hline \multirow[t]{3}{*}{ Relational attributes } & Support & $\begin{array}{c}4.94 \\
(0.089)\end{array}$ & $\begin{array}{c}5.14 \\
(0.064)\end{array}$ & 7.79 & $<0.01$ \\
\hline & Closeness & $\begin{array}{c}5.40 \\
(0.100)\end{array}$ & $\begin{array}{c}5.54 \\
(0.084)\end{array}$ & 2.56 & $>0.05$ \\
\hline & Reciprocity & $\begin{array}{c}5.44 \\
(0.090)\end{array}$ & $\begin{array}{c}5.61 \\
(0.068)\end{array}$ & 5.29 & $<0.05$ \\
\hline Trust & & $\begin{array}{c}4.81 \\
(0.074) \\
\end{array}$ & $\begin{array}{c}4.92 \\
(0.061) \\
\end{array}$ & 2.65 & $>0.05$ \\
\hline
\end{tabular}




\section{FATUROCHMAN}

Table 9.

Difference Between Aspects of Trust and Trustworthiness Based on Friend's Gender

\begin{tabular}{|c|c|c|c|c|c|}
\hline \multirow[b]{2}{*}{ Variable } & \multirow[b]{2}{*}{ Aspect } & \multicolumn{2}{|c|}{ Respondent } & \multirow[b]{2}{*}{$\mathbf{F}$} & \multirow[b]{2}{*}{$\mathbf{P}$} \\
\hline & & $\begin{array}{c}\text { Male } \\
(n=152)\end{array}$ & $\begin{array}{l}\text { Female } \\
(n=268)\end{array}$ & & \\
\hline \multirow[t]{3}{*}{ Personal attribute } & Benevolence & $\begin{array}{c}5.28 \\
(0.078)\end{array}$ & $\begin{array}{c}5.39 \\
(0.062)\end{array}$ & 3.13 & $>0.05$ \\
\hline & Competence & $\begin{array}{c}5.12 \\
(0.084)\end{array}$ & $\begin{array}{c}5.08 \\
(0.062)\end{array}$ & 0.26 & $>0.05$ \\
\hline & Integrity & $\begin{array}{c}5.39 \\
(0.077)\end{array}$ & $\begin{array}{c}5.65 \\
(0.055)\end{array}$ & 7.94 & $<0.01$ \\
\hline \multirow[t]{3}{*}{ Relational attribute } & Support & $\begin{array}{c}4.93 \\
(0.083)\end{array}$ & $\begin{array}{c}5.14 \\
(0.066)\end{array}$ & 9.79 & $<0.01$ \\
\hline & Closeness & $\begin{array}{c}5.31 \\
(0.112)\end{array}$ & $\begin{array}{c}5.67 \\
(0.078)\end{array}$ & 7.58 & $<0.01$ \\
\hline & Reciprocity & $\begin{array}{c}5.29 \\
(0.093)\end{array}$ & $\begin{array}{c}5.80 \\
(0.064)\end{array}$ & 21.54 & $<0.01$ \\
\hline Trust & & $\begin{array}{c}4.71 \\
(0.071)\end{array}$ & $\begin{array}{c}5.04 \\
(0.062)\end{array}$ & 11.61 & $<0.01$ \\
\hline
\end{tabular}

Table 10.

Differences of Aspects of Trust and Trustworthiness Based on Region

\begin{tabular}{|c|c|c|c|c|c|}
\hline \multirow[b]{2}{*}{ Variable } & \multirow[b]{2}{*}{ Aspect } & \multicolumn{2}{|c|}{ Region } & \multirow[b]{2}{*}{$\mathbf{F}$} & \multirow[b]{2}{*}{$\mathbf{P}$} \\
\hline & & $\begin{array}{c}\text { Yogyakarta } \\
(n=220)\end{array}$ & $\begin{array}{c}\text { Makassar } \\
(n=200)\end{array}$ & & \\
\hline \multirow[t]{3}{*}{ Personal attribute } & Benevolence & $\begin{array}{c}5.42 \\
(0.061)\end{array}$ & $\begin{array}{c}5.35 \\
(0.078)\end{array}$ & 0.64 & $>0.05$ \\
\hline & Competence & $\begin{array}{c}4.96 \\
(0.061)\end{array}$ & $\begin{array}{c}5.22 \\
(0.079)\end{array}$ & 6.64 & $<0.05$ \\
\hline & Integrity & $\begin{array}{c}5.59 \\
(0.056)\end{array}$ & $\begin{array}{c}5.52 \\
(0.072)\end{array}$ & 0.74 & $>0.05$ \\
\hline \multirow[t]{3}{*}{ Relational attribute } & Support & $\begin{array}{c}5.07 \\
(0.064)\end{array}$ & $\begin{array}{c}5.21 \\
(0.84)\end{array}$ & 1.79 & $>0.05$ \\
\hline & Closeness & $\begin{array}{c}5.89 \\
(0.063)\end{array}$ & $\begin{array}{c}5.15 \\
(0.111)\end{array}$ & 34.51 & $<0.01$ \\
\hline & Reciprocity & $\begin{array}{c}5.74 \\
(0.064)\end{array}$ & $\begin{array}{c}5.46 \\
(0.89)\end{array}$ & 6.95 & $<0.01$ \\
\hline Trust & & $\begin{array}{c}4.94 \\
(0.060)\end{array}$ & $\begin{array}{c}4.89 \\
(0.075)\end{array}$ & 0.21 & $>0.05$ \\
\hline
\end{tabular}




\section{Discussion}

The aim of this paper was to test a model of trust for friendship relations in Yogyakarta and Makassar. The study also investigated differences of trust and trustworthiness based on regional differences and gender. The findings reveal the following;

\section{A model of trust in friendship relations}

The current study used the trust model based on Faturochman and Minza (2014). Trust is influenced by six aspects which are categorized under two main attributes, namely personal attributes (benevolence, competence, integrity) and relational attributes (support, closeness, and reciprocity). The results of this paper showed that trust was formed by both personal and relational attributes which are composed of aspects of integrity (personal attribute), support (relational attribute), reciprocity (relational attribute); in contrast the aspects of benevolence, competence, and closeness did not show a significant effect on trust.

Trust determines the quality of relationships at different levels of analysis and in different relational contexts including friendships. Friendships are interpersonal relations characterized as voluntary, intimate, and dynamic with some degree of affection (Gifford-Smith \& Brownell, 2003). Friendship is often characterized by the presence of reciprocity, commitment, shared positive affect and a feeling of bonding. In light of these explanations, Indonesia is a country characterized by its collective nature whereby individuals have a strong interdependence with one another. This is in contrast with Americans who have individualistic tendencies, whereby individuals live autonomously and decision making prioritizes personal interest (Taylor et al., 2009). Based on this perspective, it was not surprising that support and reciprocal relations were important predictors of trust in Indonesia.

Trust in friendship relates with interpersonal trust. This means that the quality of friendship is determined by trust. This trust is formed through long lasting relationship characterized by reciprocity and bonding. In other words, trust reflects the frequency and quality of relations between one person and another (Lambright, Mischen, \& Laramee, 2010). This argument was supported by Mayer et al. (1995) who suggested that interpersonal trust is dependent on perceptions of reciprocity towards other people's competence, benevolence, and integrity. It is aligned with the study's findings that support and reciprocity were among the aspects that significantly affected trust in Indonesia.

Some research has shown that support indicates a high value in friendship relations (Rodebaugh et al., 2014; Steptoe, Shankar, Demakakos, \& Wardle, 2013). Even in the work of Afifi, Merrill, Denes, \& Davis, (2013) it was mentioned that support becomes the primary predictor for satisfaction in friendship relations. Furthermore, Cohen (2004) suggested that affection and support are main indicators of friendship relations. Friends need support, especially to increase selfacceptance. Therefore, support makes it easier for individuals to obtain trust from friends, and therefore it can be said that support positively affects trust (Salazar, 2015).

With a collective climate in Indonesia, the aspect of reciprocity has a very important role in social relations especially in friendships (Berscheid \& Regan, 2005). From a sociocultural view, there is a norm 
of reciprocity that obliges people to help others who had once helped them. The norm of reciprocity is a social norm that applies generally by building the basic concept of reciprocity or reciprocal relations in a relationship (Taylor et al., 2009).

Apart from support and reciprocal relations, the results also show that integrity can also affect trust in friendship relations. This is because integrity concerns the personal aspects which are based on values and principles; for example moral characteristics like authenticity, honesty, fairness, and consistency (Mayer, et al., 1995; Shooter, Paisley, \& Sibthorp, 2012). Integrity is also related with authenticity and individual characteristics, whereby authenticity directs an individual toward honesty in a relationship (Peterson \& Seligman, 2004). In line with that, Ilmarinen, Lonnqvist, and Paunonen (2016) suggested that honesty and openness have a positive effect on the formation and maintenance of trust in friendship relations.

Despite this, the results showed that closeness did not have a significant effect on trust. This can be because the research dealt with friendship relations, and closeness, familiarity and emotional relations that were already present in a friendship (Taylor et al., 2009). In addition, it is difficult to say that ' $A$ ' is friends with ' $\mathrm{B}$ ' without there being any closeness between the two. In other words when people are friends, this automatically implies closeness. In line with this reasoning, Karney and Bradbury (1995) stated that support would emerge when there is closeness in a friendship. Therefore closeness does not become a significant predictor because closeness is associated with support as a representation of closeness.
Furthermore, we found that competence (personal attribute), was not statistically significant in affecting trust. Although social skills, intelligence and competence are desirable features in social relations, they did not have significant effects on trust in the current study. Hareli and Weiner (2002) stated individuals tend to have negative judgments toward esteemed people. Feather (1994) suggested that high achievers may not have positive relations with others especially if they were to display undesirable characteristics like arrogance or overconfidence. The misuse of competence can create tendencies to attribute positive outcomes like success to personal factors and failures to external factors (self-serving bias). This can occur since people try to build on their self-esteem and by doing so they may misuse their competence and blame other people (Van Lange, Kruglansky \& Kruglansky, 2012).

In addition, the non-significant effect of competence in affecting trust is supported by research from Faturochman's research (2005) entitled "Envy in social relations." Faturochman (2005) categorized some main aspects that result in envy including personal development and academic achievement. The personality development and academic achievement are both aspect are aspects that can be categorized under the competence aspect. The results show that as much as $23.8 \%$ of people are jealous towards other people's personality development while $15.9 \%$ are jealous of other people's academic achievement. Competence would possibly have a significant effect for particular types of relationships for example; between teacher and students, mechanics and customers, or psychologist and client (Sears, Freedman, \& Peplau, 1985). 
Model of trust in friendship based on the regions

Yogyakarta respondents. In this research it was found that personal attributes (benevolence, integrity and competence) and relational attributes (support and reciprocity) each had effects on trust in friendship relations in Yogyakarta, while closeness (relational attribution) did not have a significant effect in friendship relations in Yogyakarta. In the past, research had shown closeness as the best predictor in friendship relations, however this does not mean that closeness automatically becomes a primary predictor of trust, and this is because closeness, as it progresses, is associated with support (Karney \& Bradbury, 1995).

Personal attributes of benevolence, integrity and competence all became significant predictors of trust because benevolence according to Mayer (1995) is a trustee's commitment to act benevolently toward the trustor, while integrity refers to a moral character which is based on good deeds and principles. The aspect being competence encompasses the individual's knowledge, particularly when used in its interactions through learning to adapt and adjust with other people (Snyder \& Lopez, 2007). Therefore, it comes to no surprise that benevolence, integrity, and competence are some of the personal attributes that affect trust.

Furthermore, relational attributes of support and reciprocity also have an effect to trust. This is because support plays an important role in friendship relations. Support can be a form of affection (Salazar, 2015) and can also be associated with closeness (Karney \& Bradbury, 1995). So it is not surprising that in Yogyakarta it is known for its warm and friendly culture in interacting with others. There is the expression "Good acts are goods rewarded; Bad acts are punished" which highlights the basic principle of reciprocity (Fehr \& Gachter, 2000; Gouldner, 1960). Reciprocity therefore is not less important than support since reciprocity functions in forming and maintaining trust in interpersonal relations (Blau, 1964; Das \& Teng, 2004; McAllister, 1995). Based on this knowledge, we can say that support and reciprocity (relational attributes) can give a significant effect toward trust.

Makassar respondents. The results of the analyses showed that from all the personal attributes (benevolence, integrity, and competence) and relational attributes (closeness, support, and reciprocity) only integrity (personal attributes) was significant. It can also be said that $44 \%$ of trust was affected by integrity in friendship relations among Makassar respondents. This shows the importance of integrity as a personal attribute attached to an individual, primarily among Makassar respondents of whom are known to have a firm hold on principles in guiding their life. Integrity is composed of moral characteristics which are strongly adhered to by individuals (Mayer, et al., 1995; Shooter et al., 2012). Even in this context, integrity concerns values of honesty and leads to self-openness in building relations with others and therefore with integrity, trust can support the positive maintenance of friendship relations (Ilmarinen, Lönnqvist, \& Paunonen, 2016).

\section{Trust based on gender}

Based on trustor's gender. The results of the research showed that there was no effect of gender on trust, however if we break down based on the trust aspects, we found that females trust their friends based on support and reciprocity more than male respondents. This can be explained by Rose and Rudolph (2006) 
who stated that females are oriented toward social relations, particularly for support and attention. They perceive friendship in more positive terms compared to males (Linden-Andersen, Markiewicz, \& Doyle 2009). In line with this, females have better interpersonal abilities and emotional understanding when interacting with other females (Rose \& Rudolph, 2006) and emphasize on social evaluation and acceptance (Burgess et al., 2006). Therefore there would be a strong relationship between female friends by sharing and supporting other friends (Billy \& Udry, 1985).

Based on trustee's gender. The results showed that trust based on a friend's gender (trustworthiness) showed that there was a difference of trustworthiness between male and female respondents. Female respondents were more trusted compared to males with higher scores for integrity (personal attribute) and all aspects of the relational attribute (closeness, support, and reciprocity). In general, friends among female participants tend to be exclusive compared to male respondents (Eder \& Hallinan, 1978). In addition, females are more able to maintain stronger relations and share their closeness with other friends (Billy \& Udry, 1985). Therefore friendship between females are more intimate compared to friendship between males. In relations to reciprocity, Phillipsen (1999) stated that females are more supportive and likely to avoid interpersonal conflict in friendship relations compared to males.

Among the four variables that affect trust on male friendship, integrity is the most important compared to support, closeness and reciprocity. In relation to this, male friendships tend to be characterized with more openness, less intimacy, dynamism, and more openness to accept new friends as time goes by, all of which represents aspects of integrity among male respondents (Belle, 1989). Chu (2005) also stated that males feel demanded to cover their vulnerabilities, prove their masculinity, and maintain their integrity when they are together with their friends.

Trustworthiness and trust between different regions

Trust based on regional differences showed that there was no difference of trust between Yogyakarta and Makassar respondents. However, if we observe the aspects of competence (personal attribute), closeness and reciprocity (relational attribute) between regions, Makassar respondents preferred competence (personal attributes), while Yogyakarta respondents preferred closeness and reciprocity (relational attributes). This means that respondents from Makassar were more trusting of a friend that could give solutions to their problems. Meanwhile in Yogyakarta, with higher scores on closeness and reciprocity, respondents were more trusting of a friend that had a warm relationship with them based on closeness and reciprocity between them.

\section{Conclusion}

The goal of this study was to test a model of trust and trustworthiness on friendship relations in Yogyakarta and Makassar based on the model proposed by Faturochman and Minza (2014). This study also tested differences of trust and trustworthiness between regions and genders. Overall the findings support the model proposed by Faturochman and Minza (2014) of which trust is affected by personal and relational attributes, however there was a difference in the Makassar 
sample such that trust was only affected by integrity (personal attribute) while other aspects did not appear to have significant effects.

This research also showed that there was no difference between males and females regarding trust. However, trust based on the friend's gender showed that females were more trustworthy than males. Furthermore, there was no difference between Yogyakarta and Makassar concerning friends' trustworthiness. Finally, this study supports the notion that trust and trustworthiness in society can be used to preserve social values and humanity within a pluralistic society.

\section{Suggestion}

Although this study has shown that trust relates to friendship relations, some references has suggested that trust is bounded by situational contexts that affect trust (Mayer et al., 1995). In relation to the three personal attributes, Mayer has not identified what situational contexts those personal attributes are most critical (Shooter et al., 2012). In the educational context it was found that beliefs that are too excessive toward a teachers expertise can hamper the students' cognitive development and critical thinking abilities (Kovač \& Kristiansen, 2010). In romantic contexts, trust toward the partner is not merely based on personal attributes of the trustee (which tend to be ignored). Instead, it depends on the meanings derived from shared experiences with the partner as well as attributional processes affected by individual characteristics of the trustor; for example attachment style, self-esteem, and self-identity (Miller \& Rempel 2004). This means that most studies thus far, lack a theoretical justification concerning specific personal attributes that are relevant in specific contexts but do not apply in other contexts.

Therefore, it is expected that more in depth research related to trust and trustworthiness can be conducted by taking into account the specific context. Such endeavor would allow the identification of trust and its application in different social contexts. In other words, this article is expected to become the start of further research which enriches psychological science, and can play a role in social life and reduce conflict and social relations.

\section{Acknowledgments}

I extend my appreciation to the Faculty of Psychology UGM who has financially supported this research. We also would like to extend our gratitude to our colleagues in the Faculty of Psychology in Universitas Negeri Makassar for their fine collaboration during this research project. Most notably Faradila, Firdaus and Nur Akmal. We would also like to say thank you to all research assistants in CICP for their hard work in making this research possible.

\section{Funding}

This research was funded by the Faculty of Psychology UGM Research Grant Year 2017 with the contract number 2758/SD/PL.03.02/VIII/2017.

\section{Contribution}

The first author was responsible for the design, research analisis, review of the first draft, and revised the paper following the first review. The second author managed the research project, collected the data, analyzed the data, reviewed the paper's draft and revised the manuscript. The third author contributed in coordinating the research, collecting data, producing a draft manuscript, and revising the manuscript.

\section{Orcid id}

Wenty Marina Minza: 0000-0002-3805-2717 


\section{References}

Afifi, T., Afifi, W., Merrill, A. F., Denes, A., \& Davis, S. (2013). "You need to stop talking about this!": Verbal rumination and the costs of social support. Human Communication Research, 39(4), 395-421. doi: $10.1111 /$ hcre.12012

Anatassia, D. F., \& Faturochman. (2014). Pencederaan kepercayaan pada relasi persahabatan remaja. (Unpublished master thesis). Faculty of Psychology Universitas Gadjah Mada, Yogyakarta.

Badewi, M.H. (2019). Nilai Siri' dan Pesse dalam kebudayaan Bugis-Makassar dan relevansinya terhadap penguatan nilai kebangsaan. Jurnal Sosiologi Walisongo, 3(1), 79-96. doi: $\underline{10.21580 / \text { jsw.2019.3.1.3291 }}$

Belle, D. Gender differences in children's social networks and supports. In: Belle, D., (Ed.) Children's social networks and social supports. New York: John Wiley \& Sons.

Bergsieker, H. B. (2012). Building, betraying, and buffering trust in interracial and same-race friendships. (Unpublished doctoral dissertation). Princeton University.

Berscheid, E. \& Regan, P. (2005). The psychology of interpersonal relationships. Upper Saddle River, NJ: Prentice Hall.

Billy, J. O., \& Udry, J. R. (1985). Patterns of adolescent friendship and effects on sexual behavior. Social Psychology Quarterly, 27-41.

Burgess, K. B., Wojslawowicz, J. C., \& Rubin, K. H. (2006). Social information processing and coping strategies of shy/withdrawn and aggressive children: Does friendship matter? Child Development, 77, 371-383.

Blau, P. M. 1964. Exchange and power in social life. New York: John Wiley.

Buchan, R. Nancy, Croson, T. Rachel \& Solnic, S. (2008). Trust and gender: An examination of behavior, biases, and beliefs in the investment game. Journal of Economic Behavior and Organization, $68,466-476$

Chu, J. Y. (2005). Adolescent boys friendships and peer group culture. In: Way, N., Hamm, KV., (Eds.) The experience of close friendships in adolescence. New Directions for Child and Adolescent Development. 25(107), 1-86. doi: $\underline{10.1002 / \mathrm{cd} .118}$

Cohen, S. (2004). Social relationships and health. American Psychologist, 59(8), 676-684.

Das, T. K., \& Teng, B.-S. (2004). The riskbased view of trust: A conceptual framework. Journal of Business and Psychology, 19, 85-116.

Eder, D., \& Hallinan, M. T. (1978). Sex differences in children's friendships. American Sociological Review, 237-250.

Fatwa, S. T. Dewi, Lars Weinehall \& Ann Öhman. (2010). 'Maintaining balance and harmony': Javanese perceptions of health and cardiovascular disease. Global Health Action, 3(1), 1-10. doi: 10.3402/gha.v3i0.4660

Faturochman. (2005). Iri dalam relasi sosial Jurnal Psikologi, 33(1), 1-16.

Faturochman \& Minza, W. M. (2014). Exploring personal and relational trustworthiness. (Unpublished manuscript). Faculty of Psychology Universitas Gadjah Mada, Yogyakarta.

Fehr, E., \& Gächter, S. (2000). Fairness and retaliation: The economics of reciprocity. The Journal of Economic Perspectives, 14(3), 159-181. doi: 10.1257/jep.14.3.159

Ferris, D. L., Lian, H., Brown, D. J., Pang, F. X., \& Keeping, L. M. (2010). Selfesteem and job performance: The moderating role of self-esteem contingencies. Personnel Psychology, 63(3), 561-593. 
Feather, N. T. (1994). Attitudes toward high achievers and reactions to their fall: Theory and research concerning tall poppies. Advances in Experimental Social Psychology, 26, 1-73.

Firmansyah, M.R., Amelia, R., Jamil, R.A., Faturochman, F., \& Minza, W.M. (2019). Benevolence, competency, and integrity: Which is more influential on trust in friendships? Jurnal Psikologi, 18(1), 91-105. doi: 10.14710/jp.18.1.91$\underline{105}$

Fiske, S. T. (2004). Social beings. New York: Wiley.

Flanagan, C, A., \& Stout, M. (2010). Developmental patterns of social trust between early and late adolescence: Age and School Climate Effects. Journal of Research on Adolescence, 20, 748-73. doi: 10.1111/j.15327795.2010.00658.x

Gouldner, A. W. (1960). The norm of reciprocity: A preliminary statement. American Sociological review, 161-178.

Gifford-Smith, M. E., \& Brownell, C. A. (2003). Childhood peer relationships: Social acceptance, friendships, and peer networks. Journal of School Psychology, 41(4), 235-284.

Hardin, R. (1996). Trustworthiness. Ethics 107(1), 26-42.

Hareli, S., \& Weiner, B. (2002). Dislike and envy as antecedents of pleasure at another's misfortune. Motivation and Emotion, 26(4), 257-277.

Hamaguchi, E. (1977 ) "Ninon Rashisa" no Saihakken. Tokyo: Nihon Keizai Shimbun-sha.

Igarashi, T., Kashima, Y, Kashima, E. S., Farsides, T., Kim, U., Strack, F., Werth, L., \& Yuki, M. (2008). Culture, trust, and social networks. Asian Journal of Social Psychology, 11, 88-101. doi: 10.1111/j.1467-839X.2007.00246.x
Ilmarinen, V. J., Lönnqvist, J. E., \& Paunonen, S. (2016). Similarityattraction effects in friendship formation: Honest platoon-mates prefer each other but dishonest do not. Personality and Individual Differences, 92, 153-158. doi: 10.1016/j.paid.2015.12.040

Karney, B. R., Bradbury, T. N. (1995). The longitudinal course of marital quality and stability: A review of theory, method, and research. Psychological Bulletin, 118(1), 3-34

Kovač, V. B. \& Kristiansen, A. (2010). Trusting trust in the context of higher education: The potential limits of the trust concept. Power and Education, 2(3), 276.2 doi: 10.2304/power.2010.2.3.276

Lambright, K. T., Mischen, P. A., \& Laramee, C. B. (2010). Building trust in public and nonprofit networks: Personal, dyadic, and third-party influences. The American Review of Public Administration, 40(1), 64-82 doi: $\underline{10.1177 / 0275074008329426}$

Linden-Andersen, S., Markiewicz, D., \& Doyle, A. (2009). Perceived similarity among adolescent friends: The role of reciprocity, friendship quality, and gender. Journal of Early Adolescence, 29, 617-637.

doi: $\underline{10.1177 / 0272431608324372}$

Mayer, R. C., Davis, J. H., \& Schoorman, F. D. (1995). An integrative model of organizational trust. Academy of Management Review, 20(3), 709-734.

McAllister, D. J. (1995). Affect-and cognitionbased trust as foundations for interpersonal cooperation in organizations. Academy of Management Journal, 38(1), 24-59.

Peterson, C., \& Seligman, M. E. (2004). Character strengths and virtues: $A$ handbook and classification (Vol. 1). Oxford: Oxford University Press. 
Phillipsen, L. C. (1999). Associations between age, gender, and group acceptance and three components of friendship quality. The Journal of Early Adolescence, 19(4), 438-464.

Rahmanawati, A., Ferdian, F. R., Widyastuti, T., Faturochman, \& Minza, W. M. (2020). How do relational and personal affect trust in adolescent friendship: An exploratory model. Humanitas, 17(1), 1-11. doi: $\underline{10.26555 / h u m a n i t a s . v 17 i 1.12700}$

Robbins, B. (2016). From the general to the specific: How social trust motivates relational trust. Social Science Research, 55, 16-30. doi: 10.1016/j.ssresearch.2015.09.004

Rodebaugh, T. L., Lim, M. H., Fernandez, K. C., Langer, J. K., Weisman, J. S., Tonge, N., Levinson, C. A., \& Shumaker, E. A. (2014). Self and friend's differing views of social anxiety disorder's effects on friendships. Journal of Abnormal Psychology, 123(4), 715-724. doi: 10.1037/abn0000015

Rose, A. J., \& Rudolph, K. D. (2006). A review of sex differences in peer relationship processes: Potential tradeoffs for the emotional and behavioral development of girls and boys. Psychological Bulletin, 132, 98-131.

Rotenberg, K. J., Fox, C., Green, S., Ruderman, L., Slater, K., Stevens, K., \& Carlo, G. (2005). Construction and validation of a children's interpersonal trust belief scale. British Journal of Developmental Psychology, 23, 271-292. doi: 10.1348/026151005X26192

Kim, P., Dirk, K., \& Cooper, C. (2009). The repair of trust: A dynamic bilateral perspective and multilevel conceptualisation. Academy of Management Review, 34(3), 401-422

Rousseau, D. M., Sitkin, S. B., Burt, R. S., \& Camerer, C. (1998). Not so different after all: A cross-discipline view of trust. Academy of Management Review, 23(3), 393-404.

Salazar, L. R. (2015). Exploring the relationship between compassion, closeness, trust, and social support in same-sex friendships. The Journal of Happiness \& Well-Being, 3(1), 15-29

Sears, D. O., Freedman, J. L., \&Peplau, L. Anne. (1985). Social psychology. NJ: Prentice Hall, Inc.

Sekhon, H., Ennew, C., Kharouf, H., \& Devlin, J. (2014). Trustworthiness andtrust: influences and implications. Journal of Marketing Management, 30(34), 409-430

Shooter, W., Paisley, K., \& Sibthorp, J. (2012). Fostering trust in outdoor leaders: The role of personal attributes. Journal of Experiential Education, 35(1), 222-237.

Simpson, J. A. (2007). Psychological foundations of trust. Current directions in Psychological Science, 16(5), 264-268.

Snyder, C. R., \& Lopez, S. J. (2007). Positive psychology: The scientific and practical explorations of human strengths. California: Sage Publications, Inc.

Steptoe, A., Shankar, A., Demakakos, P., \& Wardle, J. (2013). Social isolation, loneliness, and all-cause mortality in older men and women. Proceedings of the National Academy of Sciences, 110 (15), 5797-5801. doi: 10.1073/pnas.1219686110

Taylor, S. E., Peplau, L. A., \&Sears, D.O. (2009). Social Psychology, 12 th Edition. LA: Pearson Education-Prentince Hall.

Van Lange P. A. M. Kruglanski, A. W., \& Higgin, E. T. (2012). Handbook of the theories of social psychology. London: Sage.

Walster, E., Walster, G. W., \& Berscheid, E. (1978). Equity: Theory and research. Boston: Allyn \& Bacon. 